\title{
KOMPATIBILITAS RENCANA ZONASI WILAYAH PESISIR DAN PULAU-PULAU KECIL (RZWP3K) SEBAGAI RENCANA TATA RUANG YANG INTEGRATIF
}

\author{
(Compatibility of Zoning Plan for Coastal Areas and Small Islands as Integrated Spatial Planning)
}

\author{
Ananda Prima Yurista \\ Departemen Hukum Agraria Fakultas Hukum Universitas Gadjah Mada \\ JI. Sosio Yustisia No. 1 Bulaksumur, Sleman, D.I. Yogyakarta \\ Email: aprimayurista@gmail.com \\ Dian Agung Wicaksono \\ Departemen Hukum Tata Negara Fakultas Hukum Universitas Gadjah Mada \\ JI. Sosio Yustisia No. 1 Bulaksumur, Sleman, D.I. Yogyakarta \\ Email: dianagung@ugm.ac.id
}

Naskah diterima: 25 Juni 2017; revisi: 7 Agustus 2017; disetujui: 7 Agustus 2017

\begin{abstract}
Abstrak
Indonesia sebagai negara yang mayoritas wilayahnya berupa laut memiliki kompleksitas dalam melakukan perencanaan spasial sebagai bagian yang tidak terpisahkan dari perencanaan pembangunan nasional. Namun demikian, hukum positif Indonesia diindikasikan masih berorientasi pada perencanaan spasial di darat, yang berarti secara tidak langsung perencanaan pembangunan baru diarahkan pada pembangunan daratan. Padahal potensi ruang laut Indonesia sangat berlimpah. Hal tersebut dibuktikan dengan pengaturan dalam UU Nomor 26 Tahun 2007 tentang Penataan Ruang yang sangat berorientasi pada ruang darat dan bahkan mendelegasikan kepada pengaturan lain untuk mengatur mengenai perencanaan ruang laut. Keberadaan Rencana Zonasi Wilayah Pesisir dan Pulau-Pulau Kecil (RZWP3K) sebagai tindak lanjut dari UU Nomor 27 Tahun 2007 tentang Pengelolaan Wilayah Pesisir dan Pulau-Pulau Kecil diindikasikan menjadi dokumen yang relevan untuk mengatur mengenai perencanaan ruang laut. Apakah RZWP3K memiliki kompatibilitas sebagai rencana tata ruang laut? Penelitian ini merupakan penelitian hukum normatif untuk menggali data sekunder yang relevan melalui studi kepustakaan. Hasil dari penelitian ini menunjukkan bahwa RZWP3K tidak cukup bahkan tidak dapat difungsikan sebagai rencana tata ruang laut. RZWP3K hanya berfungsi sebagai salah satu bagian dari dokumen perencanaan ruang laut sebagaimana diamanahkan oleh UU Nomor 32 Tahun 2014 tentang Kelautan.
\end{abstract}

Kata Kunci: kompatibilitas, RZWP3K, rencana tata ruang, integratif

\begin{abstract}
Indonesia with sea space larger than land space has complexity in doing spatial planning as an integral part of national development planning. Nevertheless, Indonesia's legal system indicates that it is still oriented towards spatial planning on land, which means that the development planning is directed to the land development. Whereas the potential of Indonesian sea space is very abundant. This is proven by the provisions within the Law Number 26 of 2007 on Spatial Planning that is still much oriented to land space and even delegate to other regulations to organize on marine spatial planning. The existence of the Zoning Plan for Coastal Zone and Small Islands (RZWP3K) as follow up to Law Number 27 of 2007 on the Management of Coastal Zone and Small Islands is indicated to be the relevant document to regulate marine spatial planning. Does RZWP3K have compatibility as a marine spatial plan? This is a normative legal research to explore relevant secondary data through literature study. The results of this research indicate that RZWP3K is insufficient and can not even function as a marine spatial plan. The RZWP3K is only one part of the marine spatial planning document as mandated by Law Number 32 of 2014 on Marine.

Keywords: compatibility, RZWP $3 K$, spatial planning, integrated
\end{abstract}




\section{A. Pendahuluan}

Indonesia merupakan negara kesejahteraan (welfare state), seperti yang tercantum dalam Pembukaan UUD NRI Tahun 1945 yang menyatakan bahwa, "[...] Kemudian daripada itu untuk membentuk suatu Pemerintah Negara Indonesia yang [...] dan untuk memajukan kesejahteraan umum [...]". ${ }^{1}$ Hal ini juga tercantum dalam Pasal 33 ayat (3) UUD NRI Tahun 1945 yang menyatakan bahwa, "Bumi dan air dan kekayaan yang terkandung di dalamnya dikuasai oleh negara dan dipergunakan untuk sebesar-besarnya kemakmuran rakyat". ${ }^{2}$ Dalam rangka mewujudkan kesejahteraan tersebut, diselenggarakan pemerintahan daerah, seperti yang termaktub dalam konsideran menimbang huruf a Undang-Undang Nomor 23 Tahun 2014 tentang Pemerintahan Daerah (UU Pemda) yang menyatakan bahwa, "Penyelenggaraan pemerintahan daerah diarahkan untuk mempercepat terwujudnya kesejahteraan masyarakat melalui peningkatan pelayanan, pemberdayaan, dan peran serta masyarakat, serta peningkatan daya saing daerah dengan memperhatikan prinsip demokrasi, pemerataan, keadilan, dan kekhasan suatu daerah dalam sistem Negara Kesatuan Republik Indonesia". ${ }^{3}$ Dalam rangka mewujudkan kesejahteraan masyarakat tersebut, salah satu urusan wajib yang berkaitan dengan pelayanan dasar diantaranya meliputi pekerjaan umum dan penataan ruang. ${ }^{4}$
Urusan wajib yang berkaitan dengan pelayanan dasar meliputi penataan ruang diatur dalam UU Nomor 26 Tahun 2007 tentang Penataan Ruang (UU PR). Dalam Pasal 1 angka 1 UU PR diatur bahwa pengertian ruang meliputi ruang darat, ruang laut, dan ruang udara, ${ }^{5}$ namun secara faktual penyelenggaraan penataan ruang lebih berfokus pada penataan ruang darat. Hal ini dapat dilihat dengan, bagaimana UU PR hanya khusus mengatur perihal ruang darat dan mengamanatkan pengaturan perihal pengelolaan ruang laut dalam undang-undang tersendiri. ${ }^{6}$ Dalam perkembangannya muncul UU Nomor 27 Tahun 2007 tentang Pengelolaan Wilayah Pesisir dan Pulau-Pulau Kecil (UU PWP3K) yang meliputi kegiatan perencanaan, pemanfaatan, pengawasan, dan pengendalian terhadap interaksi manusia dalam pemanfaatan wilayah pesisir dan pulau-pulau kecil dalam upaya meningkatkan kesejahteraan masyarakat dan menjaga keutuhan Negara Kesatuan Republik Indonesia,7 yang di dalamnya mengatur perihal Rencana Wilayah Pesisir dan Pulau-Pulau Kecil (RZWP3K). Pada RZWP3K inilah diatur perihal penetapan pemanfaatan ruang laut, yang didasari pengaturan dalam Pasal 10 huruf c UU PWP3K. RZWP3K berposisi sebagai dokumen pengelolaan tersendiri yang memuat alokasi detail dari kawasan laut sesuai kebutuhan pengelolaan WP3K, yang kemudian dapat menjadi masukan bagi untuk proses

Pembukaan Undang-Undang Dasar Negara Republik Indonesia Tahun 1945.

Pasal 33 ayat (3) Undang-Undang Dasar Negara Republik Indonesia Tahun 1945.

Konsideran menimbang huruf a Undang-Undang Nomor 23 Tahun 2014 tentang Pemerintahan Daerah.

Pasal 12 ayat (1) Undang-Undang Nomor 23 Tahun 2014 tentang Pemerintahan Daerah.

Pasal 1 angka 1 Undang-Undang Nomor 26 Tahun 2007 tentang Penataan Ruang.

Pasal 6 ayat (5) Undang-Undang Nomor 26 Tahun 2007 tentang Penataan Ruang.

Yerrico Kasworo, "Urgensi Penyusunan Pengaturan Rencana Zonasi Wilayah Pesisir dan Pulau-Pulau Kecil”, Rechtsvinding Online, (2017), http://rechtsvinding.bphn.go.id/view/view_online.php?id=233 (diakses 15 Juni 2017). 
penyusunan atau peninjauan kembali RTRW, tepatnya untuk ruang laut. ${ }^{8}$

Secara normatif, RZWP3K (sebagai rencana tata ruang laut) dan RTRW (sebagai rencana tata ruang darat) harusnya disusun secara terintegrasi, namun dalam banyak praktik di daerah, RZWP3K dan RTRW disusun oleh perangkat daerah yang berbeda, yakni Dinas Pertanahan dan Tata Ruang dan Dinas Perikanan dan Kelautan. Selain itu, RZWP3K hanya ada di level Provinsi, padahal basis perencanaan spasial berasal dari level Kabupaten/Kota. Dengan demikian, rumusan masalah yang akan dikaji adalah: Pertama, bagaimana konstruksi hukum dokumen RZWP3K dalam perencanaan spasial? Kedua, bagaimana kompatibilitas RZWP3K sebagai rencana tata ruang laut yang integratif dengan dokumen perencanaan spasial lainnya?

\section{B. Metode Penelitian}

Penelitian ini dilakukan dengan menggunakan pendekatan yuridis normatif, ${ }^{9}$ karena bahan pustaka digunakan sebagai bahan utama yang terdiri dari 3 (tiga) bahan hukum yaitu: (1) bahan hukum primer yang terdiri dari norma dasar atau kaidah, ketentuan atau peraturan dasar, serta peraturan perundangundangan; (2) bahan hukum sekunder adalah bahan hukum yang memberikan penjelasan lebih lanjut dari bahan hukum primer berupa literatur, artikel jurnal, dan juga hasil penelitian yang membahas tentang hak menguasai negara, politik hukum, teori penafsiran konstitusi, dan teori perjenjangan norma; ${ }^{10}$ dan (3) bahan hukum tersier adalah bahan yang memberikan petunjuk maupun penjelasan terhadap bahan hukum primer dan bahan hukum sekunder, contohnya adalah kamus, ensiklopedi, dan lainlain.

Cara pengambilan data dalam penelitian ini adalah dengan melakukan studi pustaka terhadap buku-buku, artikel-artikel, hasil-hasil penelitian, dan peraturan perundang-undangan, serta pendapat ahli yang berkaitan dengan konsepsi RZWP3K, rencana tata ruang laut, dan pengendalian pemanfaatan ruang laut. Dalam hal analisis data dilakukan secara deskriptif kualitatif, yaitu dengan melakukan analisis yang pada dasarnya dikembalikan pada tiga aspek, yaitu mengklasifikasi, membandingkan, dan menghubungkan. Dengan perkataan lain, seorang peneliti yang mempergunakan metode kualitatif, tidaklah semata-mata bertujuan mengungkapkan kebenaran belaka, akan tetapi untuk memahami kebenaran tersebut. Terhadap data-data yang telah terkumpul dari penelitian kepustakaan selanjutnya akan dianalisis secara kualitatif untuk menjawab permasalahan penelitian yang diajukan.

\section{Pembahasan}

\section{Konstruksi Hukum Dokumen RZWP3K dalam Perencanaan Spasial}

Politik hukum perencanaan spasial di Indonesia tidak dapat dilepaskan dari perkembanganpengaturantentangperencanaan pembangunan di Indonesia. Pasca berlakunya Undang-Undang Nomor 24 Tahun 2005 tentang

$8 \quad$ Iman Soedradjat, "Penyelarasan Rencana Zonasi Wilayah Pesisir dan Pulau-Pulau Kecil (RZWP3K) dan Rencana Tata Ruang Wilayah (RTRW)”, Buletin Tata Ruang \& Pertanahan, Edisi I (2013), hlm. 15.

9 Soedjono Soekanto dan Sri Mamudji, Penelitian Hukum Normatif: Suatu Tinjauan Singkat, (Jakarta: Raja Grafindo Persada, 1994), hlm. 13.

10 Soerdjono Soekanto, Pengantar Penelitian Hukum, (Jakarta: UI Press, 1986), hlm. 132. 
Sistem Perencanaan Pembangunan Nasional (UU SPPN), arah perencanaan pembangunan di Indonesia disusun secara lebih integratif antara Pemerintah Pusat dan Pemerintah Daerah. Perencanaan pembangunan ini kemudian diintegrasikan dengan perencanaan spasial di Indonesia. Melalui UU PR, perencanaan pembangunan dihubungkan secara erat perencanaan spasial. Pada awalnya penyusunan perencanaan spasial harus didasarkan pada perencanaan pembangunan, namun secara simultan dan berkelanjutan kedua dokumen perencanaan tersebut harus saling mengacu dan memperhatikan dalam penyusunannya. ${ }^{11}$

Dengan demikian, dapat disimpulkan bahwa pada awalnya kebijakan pembangunanlah yang membentuk dan mempengaruhi kondisi ruang, namun selanjutnya kebijakan pembangunan dan kondisi ruang harus diharmonisasikan dan disinergikan, terlebih dengan memperhatikan kondisi lingkungan, sebagaimana telah ditegaskan dalam Pasal 16 ayat (2) UU Nomor 32 Tahun 2009 tentang Perlindungan dan Pengelolaan Lingkungan Hidup (UU PPLH) yang menyatakan Pemerintah dan pemerintah daerah wajib melaksanakan Kajian Lingkungan Hidup Strategis dalam penyusunan dan evaluasi: a. rencana tata ruang wilayah (RTRW) beserta rencana rincinya, rencana pembangunan jangka panjang (RPJP), dan rencana pembangunan jangka menengah (RPJM) nasional, provinsi, dan kabupaten/kota; dan b. kebijakan, rencana, dan/ atau program yang berpotensi menimbulkan dampak dan/atau risiko lingkungan hidup. ${ }^{12}$

Memperhatikan pengaturan tersebut dapat dilihat bahwa lingkungan hidup berupa ruang atau spasial menjadi unsur yang penting dalam pembangunan nasional, yang mana pada satu sisi pembangunan harus membentuk ruang, namun di sisi yang lain pembangunan juga harus memperhatikan kondisi ruang yang ada. Pemahaman tersebut memberikan penegasan bahwa dalam perencanaan pembangunan yang holistik, aspek keruangan menjadi aspek yang mau tidak mau harus diperhatikan.

Pengaturan dalam UU PR menegaskan ruang yang dimaksud dalam perencanaan ruang adalah wadah yang meliputi ruang darat, ruang laut, dan ruang udara, termasuk ruang di dalam bumi sebagai satu kesatuan wilayah, tempat manusia dan makhluk lain hidup, melakukan kegiatan, dan memelihara kelangsungan hidupnya. ${ }^{13}$ Merujuk pada definisi otentik tersebut, terlihat lingkup dari ruang yang harus direncanakan, yaitu ruang darat, ruang laut, ruang udara, dan ruang di dalam bumi. Khusus untuk ruang laut dan ruang udara, meski secara aktual penataan terhadap ruang laut dan udara hampir tidak pernah dilakukan, namun pencantuman kedua ruang tersebut dalam UU perlu dilakukan, karena secara geopolitik merupakan satu kesatuan geografis

11 Lihat Pasal 19 huruf f Undang-Undang Nomor 26 Tahun 2007 tentang Penataan Ruang, yang berbunyi, "Penyusunan Rencana Tata Ruang Wilayah Nasional harus memperhatikan: [...] f. rencana pembangunan jangka panjang nasional”, yang mana di sisi yang lain Pasal 20 ayat (2) Undang-Undang Nomor 26 Tahun 2007 tentang Penataan Ruang, yang berbunyi, "Rencana Tata Ruang Wilayah Nasional menjadi pedoman untuk: a. penyusunan rencana pembangunan jangka panjang nasional; b. penyusunan rencana pembangunan jangka menengah nasional; [...]".

12 Pasal 16 ayat (2) Undang-Undang Nomor 32 Tahun 2009 tentang Perlindungan dan Pengelolaan Lingkungan Hidup.

13 Pasal 1 angka 1 Undang-Undang Nomor 26 Tahun 2007 tentang Penataan Ruang. 
yang tidak dapat dipisahkan dan berkait dengan kedaulatan negara. ${ }^{14}$ Pertanyaan yang patut untuk ditelaah kemudian adalah bagaimana pengaturan mengenai keempat lingkup ruang tersebut dalam hukum positif Indonesia?

Melalui penelusuran dalam UU PR dengan mudah dapat diketemukan bahwa UU PR hanya memiliki orientasi untuk mengatur mengenai ruang darat. Salah satu indikasi tersebut terlihat dari pengaturan dalam UU PR yang justru mendelegasikan pengaturan terkait pengelolaan ruang laut dan ruang udara untuk diatur dengan undang-undang tersendiri. ${ }^{15}$ Walaupun dalam pengaturan sebelumnya diatur bahwa, "Penataan ruang wilayah nasional meliputi ruang wilayah yurisdiksi dan wilayah kedaulatan nasional yang mencakup ruang darat, ruang laut, dan ruang udara, termasuk ruang di dalam bumi sebagai satu kesatuan", ${ }^{16}$ namun pengaturan tersebut dinegasikan dengan adanya delegasi pengaturan pada UU yang bersifat sui generis.

Bahkan pengaturan tersebut bukan hanya dalam koridor pengaturan lebih lanjut, namun merupakan pengaturan didelegasikan seutuhnya. Hal tersebut dapat dilihat dari rumusan "Ruang laut dan ruang udara, pengelolaannya diatur dengan undang-undang tersendiri", yang berarti materi muatan yang didelegasikan sama sekali belum diatur pokokpokoknya di dalam Peraturan Perundangundangan yang mendelegasikan dan materi muatan itu harus diatur di dalam Peraturan
Perundang-undangan yang diberi delegasi dan tidak boleh didelegasikan lebih lanjut ke Peraturan Perundang-undangan yang lebih rendah (subdelegasi). ${ }^{17}$

Keleluasaan yang diberikan oleh UU PR kemudian diwujudkan dengan pengaturan pada UU PWP3K yang mengamanatkan pembentukan beberapa dokumen perencanaan, yaitu: ${ }^{18}$

a. Rencana Strategis Wilayah Pesisir dan PulauPulau Kecil yang selanjutnya disebut RSWP3-K;

b. Rencana Zonasi Wilayah Pesisir dan PulauPulau Kecil yang selanjutnya disebut RZWP3-K;

c. Rencana Pengelolaan Wilayah Pesisir dan Pulau-Pulau Kecil yang selanjutnya disebut RPWP-3-K; dan

d. Rencana Aksi Pengelolaan Wilayah Pesisir dan Pulau-Pulau Kecil yang selanjutnya disebut RAPWP-3-K.

Merujuk pada pengertian yang dituangkan pada Ketentuan Umum UU PWP3K, terlihat bahwa RZWP3K merupakan dokumen perencanaan yang dapat disebut paling determinatif dalam perencanaan spasial, mengingat Rencana Zonasi adalah rencana yang menentukan arah penggunaan sumber daya tiap-tiap satuan perencanaan disertai dengan penetapan struktur dan pola ruang pada Kawasan perencanaan yang memuat kegiatan yang boleh dilakukan dan tidak boleh dilakukan serta kegiatan yang hanya dapat dilakukan

14 Haris Syahbuddin, "Penataan Ruang Wilayah: Perjalanan Panjang Bangsa”, Inovasi, Vol. 7, No. XVIII (Juni 2006), hlm. 1.

15 Pasal 6 ayat (5) Undang-Undang Nomor 26 Tahun 2007 tentang Penataan Ruang.

16 Pasal 6 ayat (3) Undang-Undang Nomor 26 Tahun 2007 tentang Penataan Ruang.

17 Lampiran II angka 203 Undang-Undang Nomor 12 Tahun 2011 tentang Pembentukan Peraturan Perundangundangan.

18 Pasal 7 ayat (1) Undang-Undang Nomor 27 Tahun 2007 tentang Pengelolaan Wilayah Pesisir dan Pulau-Pulau Kecil. 
setelah memperoleh izin. ${ }^{19}$ Mendasarkan pada definisi tersebut, RZWP3K kemudian disinyalir merupakan dokumen perencanaan yang dapat difungsikan sebagai dokumen perencanaan tata ruang laut.

Lebih lanjut untuk mengetahui konstruksi hukum dokumen RZWP3K sebagai dokumen perencanaan spasial, maka perlu untuk diperbandingkan dengan dokumen perencanaan spasial yang lain, yaitu Rencana Tata Ruang Wilayah (RTRW) sebagai dokumen perencanaan spasial, khususnya perencanaan ruang darat sebagaimana amanat UU PR. Pertama, Tahapan

Penyusunan Dokumen. Proses penyusunan Rencana Tata Ruang Wilayah (RTRW) meliputi:20

a. proses penyusunan rencana tata ruang;

b. pelibatan peran masyarakat dalam perumusan konsepsi rencana tata ruang; dan

c. pembahasan rancangan rencana tata ruang oleh pemangku kepentingan.

Adapun proses penyusunan rencana tata ruang dilakukan melalui tahapan: (a) persiapan penyusunan rencana tata ruang; (b) pengumpulan data; (c) pengolahan dan analisis data; (c) perumusan konsepsi rencana tata ruang; dan (e) penyusunan rancangan peraturan perundang-undangan tentang rencana tata ruang. ${ }^{21}$ Proses penyusunan rencana tata ruang menghasilkan dokumen rancangan rencana tata ruang dalam bentuk rancangan peraturan perundang-undangan tentang rencana tata ruang beserta lampirannya. ${ }^{22}$

Bila hendak diperbandingkan dalam penyusunan RZWP3K, meliputi tahapan:23

a. usulan penyusunan dilakukan oleh Pemerintah Daerah dan dunia usaha;

b. mekanisme penyusunan di tingkat provinsi dan kabupaten/kota dilakukan dengan melibatkan Masyarakat; dan

c. Pemerintah Daerah berkewajiban menyebarluaskan konsep RZWP3K untuk mendapatkan masukan, tanggapan, dan saran perbaikan.

Secara sederhana, perbandingan proses penyusunan disajikan dalam tabel berikut ini: 
Tabel 1. Perbandingan Proses Penyusunan RTRW dan RZWP3K

\begin{tabular}{ll}
\hline Proses Penyusunan RTRW & Proses Penyusunan RZWP3K \\
\hline $\begin{array}{l}\text { Proses penyusunan rencana tata ruang, } \\
\text { dilakukan melalui tahapan: }\end{array}$ & $\begin{array}{l}\text { Usulan penyusunan dilakukan oleh } \\
\text { Pemerintah Daerah dan dunia usaha; }\end{array}$ \\
$\begin{array}{l}\text { a. persiapan penyusunan rencana tata ruang; } \\
\text { b. pengumpulan data; }\end{array}$ & \\
$\begin{array}{l}\text { c. pengolahan dan analisis data; } \\
\text { d. perumusan konsepsi rencana tata ruang; dan } \\
\text { e. penyusunan rancangan peraturan perundang- } \\
\text { undangan tentang rencana tata ruang. }\end{array}$ & \\
\hline $\begin{array}{l}\text { Pelibatan peran masyarakat dalam perumusan konsepsi } \\
\text { rencana tata ruang; dan }\end{array}$ & $\begin{array}{l}\text { Mekanisme penyusunan di tingkat provinsi } \\
\text { dan kabupaten/kota dilakukan dengan } \\
\text { melibatkan Masyarakat; dan }\end{array}$ \\
\hline $\begin{array}{l}\text { Pembahasan rancangan rencana tata ruang oleh } \\
\text { pemangku kepentingan. }\end{array}$ & $\begin{array}{l}\text { Pemerintah Daerah berkewajiban } \\
\text { menyebarluaskan konsep RZWP3K untuk } \\
\text { mendapatkan masukan, tanggapan, dan }\end{array}$ \\
\end{tabular}

Sumber: Diolah Penulis, 2017.

Berdasarkan uraian tersebut maka dapat disimpulkan bahwa baik RZWP3K dan RTRW sama-sama: (a) melibatkan masyarakat dalam penyusunan/perumusan konsepnya; dan (b) adanya upaya untuk mendapatkan masukan, tanggapan, dan saran perbaikan dalam pembahasan rancangan rencana tata ruang. Adapun yang membedakan adalah usulan penyusunan RZWP3K dilakukan oleh dunia bisnis.

Kedua, Kelembagaan Penyusun Dokumen. Merujuk pada Lampiran UU Pemda terkait Pembagian Urusan Bidang Kelautan dan Perikanan, Sub Urusan Kelautan, Pesisir, dan Pulau-Pulau Kecil, kewenangan perihal urusan dan sub urusan tersebut hanya ada pada Pemerintah Pusat dan Provinsi, namun tidak pada Pemerintah Kabupaten/Kota. ${ }^{24}$ Dalam hal Pembagian Urusan Pemerintahan Bidang Pekerjaan Umum dan Penataan Ruang, Sub Urusan Penataan Ruang, baik pemerintah pusat, pemerintah provinsi, dan pemerintah kabupaten/kota mempunyai kewenangan yang sama, yakni untuk melaksanakan penyelenggaraan penataan ruang di level nasional, provinsi, dan kabupaten/kota. ${ }^{25}$ Dengan demikian, maka RZWP3K hanya dapat dibentuk pada level provinsi, sedangkan RTRW dapat dibentuk pada level nasional, provinsi, maupun kabupaten/kota. Dengan demikian, menjadi sangat penting untuk memikirkan bagaimana kemudian sinkronisasi dapat dilakukan pada tingkat kabupaten/kota. Selain itu, problematika penyusunan RTRW dan RZWP3K pada level Provinsi juga patut untuk ditelaah, hal ini dikarenakan RTRW dan RZWP3K

\footnotetext{
24 Lampiran Undang-Undang Nomor 23 Tahun 2014 tentang Pemerintah Daerah.
}

25 Lampiran Undang-Undang Nomor 23 Tahun 2014 tentang Pemerintah Daerah. 
terdistribusi pada sub urusan yang berbeda pada urusan pemerintahan yang berbeda. Pembedaan tersebut memberikan konsekuensi berbedanya perangkat daerah yang bertugas untuk melaksanakan kewenangan tersebut. Misalnya penyusunan RTRW akan menjadi domain dari Dinas Pertanahan dan Tata Ruang, sedangkan penyusunan RZWP3K menjadi domain kewenangan dari Dinas Kelautan dan Perikanan. Hal ini juga menjadi titik kelemahan untuk melakukan sinkronisasi substansi antara RTRW dan RZWP3K. Terlebih ego sektoral antara perangkat daerah juga menimbulkan potensi permasalahan dalam implementasi kedua dokumen perencanaan tersebut.

Ketiga, Sistematika Dokumen. Sistematika dokumen RTRW terdiri dari: (a) tujuan, kebijakan, dan strategi penataan ruang; (b) rencana struktur ruang; (c) rencana pola ruang; (d) penetapan kawasan strategis; (e) arahan pemanfaatan ruang; dan (f) arahan pengendalian pemanfaatan ruang. ${ }^{26}$ Adapun sistematika dokumen RZWP3K terdiri dari: (a) pengalokasian ruang dalam Kawasan Pemanfaatan Umum, Kawasan Konservasi, Kawasan Strategis Nasional Tertentu, dan alur laut; (b) keterkaitan antara ekosistem darat dan ekosistem laut dalam suatu bioekoregion; (c) penetapan pemanfaatan ruang laut; dan (d) penetapan prioritas kawasan laut untuk tujuan konservasi, sosial budaya, ekonomi, transportasi laut, industri strategis, serta pertanahan dan keamanan. ${ }^{27}$ Secara sederhana, sistematika dokumen disajikan dalam tabel berikut ini:

Tabel 2. Perbandingan Sistematika Dokumen RTRW dan RZWP3K

\section{Sistematika Dokumen RTRW}

a. tujuan, kebijakan, dan strategi penataan ruang;

\section{Sistematika Dokumen RZWP3K}

a. pengalokasian ruang dalam Kawasan Pemanfaatan Umum, Kawasan Konservasi, Kawasan Strategis Nasional Tertentu, dan alur laut;

b. rencana struktur ruang;

b. keterkaitan antara ekosistem darat dan ekosistem laut dalam suatu bioekoregion;

c. rencana pola ruang;

c. penetapan pemanfaatan ruang laut; dan

d. penetapan kawasan strategis;

e. arahan pemanfaatan ruang; dan

f. arahan pengendalian pemanfaatan ruang. konservasi, sosial budaya, ekonomi, transportasi laut, industri strategis, serta pertanahan dan keamanan.

Sumber: Diolah Penulis, 2017.

Pasal 23 ayat (1) Undang-Undang Nomor 26 Tahun 2007 tentang Penataan Ruang.

Pasal 10 huruf a, b, c, d Undang-Undang Nomor 27 Tahun 2007 tentang Pengelolaan Wilayah Pesisir dan PulauPulau Kecil.

28 Pasal 1 angka 14 Undang-Undang Nomor 27 Tahun 2007 tentang Pengelolaan Wilayah Pesisir dan Pulau-Pulau Kecil. 
Berdasarkan uraian tersebut, maka terdapat perbedaan struktur antara RTRW dengan RZWP3K, khususnya perihal tidak adanya ketentuan perihal struktur ruang dan pola ruang. Padahal dalam Pasal 1 angka 14 UU PWP3K ditekankan bahwa pengertian dari rencana zonasi terdapat struktur ruang dan pola ruang. ${ }^{29}$

\section{Keempat, Penuangan Dokumen dalam} Produk Hukum. Merujuk pada uraian sebelumnya, RZWP3K dituangkan dalam produk hukum berupa Peraturan Daerah Provinsi, sedangkan RTRW dituangkan dalam produk hukum berupa Peraturan Daerah Provinsi atau Kabupaten/Kota. Hal ini tidak bisa dilepaskan terkait kewenangan pembentukan RZWP3K dan RTRW yang didistribusikan secara berbeda dalam hukum positif Indonesia.
Namun demikian, terlepas dari perbandingan antara RTRW yang didaulat sebagai rencana tata ruang darat dan RZWP3K yang diklaim sebagai rencana tata ruang laut, perlu untuk kemudian mencermati pengaturan dalam Pasal 43 ayat (1) UU Nomor 32 Tahun 2014 tentang Kelautan (UU Kelautan), yang menegaskan bahwa perencanaan ruang Laut meliputi: a. perencanaan tata ruang Laut nasional; b. perencanaan zonasi wilayah pesisir dan pulaupulau kecil; dan c. perencanaan zonasi kawasan Laut. ${ }^{30}$ Bila merujuk pada pengaturan tersebut, maka dokumen perencanaan ruang laut secara definitif merupakan hasil dari perencanaan ruang laut, yaitu: ${ }^{31}$

Tabel 3. Perencanaan Ruang Laut

\begin{tabular}{|c|c|}
\hline Proses Perencanaan & Dokumen Perencanaan yang Dihasilkan \\
\hline \multirow[t]{2}{*}{ Perencanaan tata ruang Laut nasional } & rencana tata ruang \\
\hline & Laut nasional \\
\hline $\begin{array}{l}\text { Perencanaan zonasi wilayah pesisir dan pulau- } \\
\text { pulau kecil }\end{array}$ & $\begin{array}{l}\text { Rencana Zonasi Wilayah Pesisir dan Pulau-Pulau Kecil } \\
\text { (RZWP3K) }\end{array}$ \\
\hline Perencanaan zonasi kawasan Laut & $\begin{array}{l}\text { - rencana zonasi kawasan strategis nasional } \\
\text { - rencana zonasi kawasan strategis nasional tertentu } \\
\text { - rencana zonasi kawasan antarwilayah. }\end{array}$ \\
\hline
\end{tabular}

Sumber: Diolah Penulis, 2017.

\footnotetext{
29 Pasal 1 angka 14 Undang-Undang Nomor 27 Tahun 2007 tentang Pengelolaan Wilayah Pesisir dan Pulau-Pulau Kecil.

30 Pasal 43 ayat (1) Undang-Undang Nomor 32 Tahun 2014 tentang Kelautan.

31 Pasal 43 ayat (1)-(4) Undang-Undang Nomor 32 Tahun 2014 tentang Kelautan.
} 
Lebih lanjut dari pengaturan di atas, terlihat bahwa dari perencanaan ruang laut baru terdapat 1 (satu) dokumen perencanaan yang definitif, yaitu RZWP3K. Selebihnya, dokumen perencanaan ruang laut yang diamanatkan oleh UU Kelautan masih menunggu pengaturan lebih lanjut dengan Peraturan Pemerintah, ${ }^{32}$ yang mana sampai saat ini belum ${ }^{33}$ terdapat peraturan pelaksanaan tersebut. Walaupun dalam perspektif yang lain, terdapat anggapan bahwa UU Kelautan sebenarnya hanya berfokus pada wilayah laut di atas 12 mil yang merupakan kewenangan pusat, sedangkan UU PWP3K untuk wilayah kurang dari 12 mil yang merupakan kewenangan daerah. ${ }^{34}$ Namun mengingat sejatinya ruang laut merupakan satu kesatuan sebagai perwujudan konsep negara kesatuan, yang mana terdapat kebulatan urusan (eenheid) yang dimiliki oleh Pemerintah Pusat, maka konteks UU Kelautan harus dilihat sebagai sebuah perencanaan ruang laut yang integratif antara Pemerintah Pusat dan Pemerintah Daerah. Dengan demikian, dapat disimpulkan bahwa konstruksi hukum atas RZWP3K memang tidak dapat diklaim sebagai rencana tata ruang laut secara utuh, mengingat RZWP3K hanyalah merupakan bagian dari perencanaan ruang laut di Indonesia.

\section{Kompatibilitas RZWP3K sebagai Rencana Tata Ruang yang Integratif}

Lebih lanjut dalam menganalisis kompatibilitas RZWP3K sebagai rencana tata ruang yang integratif, perlu untuk mencermati pengaturan RZWP3K dalam hukum positif Indonesia. Hal tersebut dapat diuraikan sebagai berikut:

a. RZWP3K merupakan salah satu bentuk perencanaan pengelolaan wilayah pesisir dan pulau-pulau kecil. ${ }^{35}$

b. RZWP3K merupakan arahan pemanfaatan sumber daya di Wilayah Pesisir dan PulauPulau Kecil pemerintah provinsi dan/atau pemerintah kabupaten/kota. ${ }^{36}$

c. RZWP3K harus serasi, selaras, dan seimbang dengan Rencana Tata Ruang Wilayah (RTRW) pemerintah provinsi atau pemerintah kabupaten/kota. ${ }^{37}$

d. Perencanaan RZWP3K dilakukan dengan mempertimbangkan: (a) keserasian, keselarasan, dan keseimbangan dengan daya dukung ekosistem, fungsi pemanfaatan dan fungsi perlindungan, dimensi ruang dan waktu, dimensi teknologi dan sosial budaya, serta fungsi pertahanan dan keamanan; (b) keterpaduan pemanfaatan berbagai jenis sumber daya, fungsi, estetika lingkungan, dan kualitas lahan pesisir; dan

Pasal 43 ayat (5) Undang-Undang Nomor 32 Tahun 2014 tentang Kelautan.

33 Saat ini masih dalam proses harmonisasi penyusun Rancangan Peraturan Pemerintah tentang Rencana Tata Ruang Laut Nasional. Lihat dalam DJPP Kemenkumham, "RPP tentang Rencana Tata Ruang Laut Nasional”, http://ditjenpp.kemenkumham.go.id/kegiatan-umum/3150-rpp-tentang-rencana-tata-ruang-laut-nasional. html (diakses 15 Juni 2017).

34 Arif Satria, Politik Kelautan dan Perikanan (Jakarta: Yayasan Pustaka Obor Indonesia, 2015), hlm. 141.

35 Pasal 7 ayat (1) huruf b Undang-Undang Nomor 27 Tahun 2007 tentang Pengelolaan Wilayah Pesisir dan PulauPulau Kecil.

36 Pasal 9 ayat (1) Undang-Undang Nomor 27 Tahun 2007 tentang Pengelolaan Wilayah Pesisir dan Pulau-Pulau Kecil.

37 Pasal 9 ayat (2) Undang-Undang Nomor 27 Tahun 2007 tentang Pengelolaan Wilayah Pesisir dan Pulau-Pulau Kecil. 
(c) kewajiban untuk mengalokasikan ruang dan akses Masyarakat dalam pemanfaatan Wilayah Pesisir dan Pulau-Pulau Kecil yang mempunyai fungsi sosial dan ekonomi. ${ }^{38}$

e. RZWP3K ditetapkan dalam Peraturan Daerah dan berlaku selama 20 (dua puluh) tahun dan dapat ditinjau kembali setiap 5 (lima) tahun. ${ }^{39}$

f. RZWP3K Provinsi terdiri atas: (a) pengalokasian ruang dalam Kawasan Pemanfaatan Umum, Kawasan Konservasi, Kawasan Strategis Nasional Tertentu, dan alur laut; (b) keterkaitan antara Ekosistem darat dan Ekosistem laut dalam suatu Bioekoregion; (c) penetapan pemanfaatan ruang laut; dan (e) penetapan prioritas Kawasan laut untuk tujuan konservasi, sosial budaya, ekonomi, transportasi laut, industri strategis, serta pertahanan dan keamanan. ${ }^{40}$

g. RZWP3K Kabupaten/Kota berisi arahan tentang: (a) alokasi ruang dalam Rencana Kawasan Pemanfaatan Umum, rencana Kawasan Konservasi, rencana Kawasan Strategis Nasional Tertentu, dan rencana alur; (b) keterkaitan antarekosistem Pesisir dan Pulau-Pulau Kecil dalam suatu Bioekoregion. ${ }^{41}$ h. Penyusunan RZWP3K diwajibkan mengikuti dan memadukan rencana Pemerintah dan Pemerintah Daerah dengan memperhatikan Kawasan, Zona, dan/atau Alur Laut yang telah ditetapkan sesuai dengan peraturan perundang-undangan. ${ }^{42}$

i. Usulan penyusunan RZWP3K dilakukan oleh Pemerintah Daerah serta dunia usaha. ${ }^{43}$

j. Mekanisme penyusunan RZWP3K pemerintah provinsi dan pemerintah kabupaten/kota dilakukan dengan melibatkan Masyarakat. ${ }^{44}$

k. Konsep RZWP3K wajib disebarluaskan oleh Pemerintah Daerah untuk mendapatkan masukan, tanggapan, dan saran perbaikan. ${ }^{45}$

Berbekal uraian pengaturan tersebut, sekaligus mengelaborasi pernyataan bahwa RZWP3K bukan merupakan rencana tata ruang laut, melainkan hanya bagian dari perencanaan ruang laut, maka analisis kompatibilitas RZWP3K dapat diuraikan sebagai berikut: Pertama, Diferensiasi Definisi. Berdasarkan Pasal 1 angka 2 dan 3 UU PWP3K dijelaskan bahwa pengertian wilayah pesisir adalah daerah peralihan antara ekosistem darat dan laut yang dipengaruhi perubahan di darat dan di laut, pengertian pulau adalah pulau dengan

38 Pasal 9 ayat (3) Undang-Undang Nomor 27 Tahun 2007 tentang Pengelolaan Wilayah Pesisir dan Pulau-Pulau Kecil.

39 Pasal 9 ayat (4) dan (5) Undang-Undang Nomor 27 Tahun 2007 tentang Pengelolaan Wilayah Pesisir dan PulauPulau Kecil.

40 Pasal 10 Undang-Undang Nomor 27 Tahun 2007 tentang Pengelolaan Wilayah Pesisir dan Pulau-Pulau Kecil.

41 Pasal 11 ayat (1) Undang-Undang Nomor 27 Tahun 2007 tentang Pengelolaan Wilayah Pesisir dan Pulau-Pulau Kecil.

42 Pasal 11 ayat (2) Undang-Undang Nomor 27 Tahun 2007 tentang Pengelolaan Wilayah Pesisir dan Pulau-Pulau Kecil.

43 Pasal 14 ayat (1) Undang-Undang Nomor 27 Tahun 2007 tentang Pengelolaan Wilayah Pesisir dan Pulau-Pulau Kecil.

44 Pasal 14 ayat (2) Undang-Undang Nomor 27 Tahun 2007 tentang Pengelolaan Wilayah Pesisir dan Pulau-Pulau Kecil.

45 Pasal 14 ayat (3) Undang-Undang Nomor 27 Tahun 2007 tentang Pengelolaan Wilayah Pesisir dan Pulau-Pulau Kecil. 
luas lebih kecil atau sama dengan $2000 \mathrm{~km}^{2},{ }^{46}$ sedangkan pengertian laut dalam Pasal 1 angka 1 UU Kelautan adalah ruang perairan di muka bumi yang menghubungkan daratan dengan daratan dan bentuk-bentuk alamiah lainnya, yang merupakan kesatuan geografis dan ekologis beserta segenap unsur terkait, dan yang batas dan sistemnya ditentukan oleh peraturan perundang-undangan dan hukum internasional. ${ }^{47}$ Berdasarkan hal tersebut, maka pengertian laut dan wilayah pesisir dan pulaupulau kecilberbeda, yang dapat diuraikan sebagai berikut: Pertama, pemanfaatan ruang pesisir secara berkelanjutan harus memperhatikan dua aspek kewilayahan, yaitu aspek ruang daratan dan aspek ruang perairan (laut) ${ }^{48}$ dan Kedua, kawasan pesisir terdiri dari wilayah daratan (teresterial) dan wilayah perairan mempunyai karakteristik wilayah sangat dinamis dan saling mempengaruhi satu dengan yang lainnya baik secara ekologi maupun sosial. ${ }^{49}$ sehingga tidak tepat apabila RZWP3K disamakan dengan rencana tata ruang laut, bahkan tidak tepat jika RZWP3K mencakup rencana tata ruang laut dan penetapan pemanfaatan ruang laut.

Kedua, Diferensiasi Substansi. UU PWP3K menyatakan bahwa, "RZWP3K merupakan arahan pemanfaatan sumber daya di Wilayah Pesisir dan Pulau-Pulau Kecil pemerintah provinsi dan/atau pemerintah kabupaten/ kota", ${ }^{50}$ kemudian UU PWP3K juga mengatur bahwa RZWP3K mencakup diantaranya penetapan pemanfaatan ruang laut ${ }^{51}$. Berdasarkan uraian tersebut, dapat dilihat bahwa kedua Pasal tersebut bertentangan karena dengan merujuk pada Pasal 1 angka 2 dan 3 UU PWP3K dan Pasal 1 angka 1 UU Kelautan, maka apabila RZWP3K dimaksudkan sebagai arahan pemanfaatan sumber daya di Wilayah Pesisir dan Pulau-Pulau Kecil, maka RZWP3K tidak dapat mencakup penetapan ruang laut, karena sumber daya di Wilayah Pesisir dan Pulau-Pulau kecil tidak mencakup ruang laut, namun justru ruang laut lah yang dapat mencakup wilayah pesisir dan pulaupulau kecil.

Ketiga, Diferensiasi Kewenangan. RZWP3K mencakup perihal arahan pemanfaatan ${ }^{52}$ dan arahan penetapan pemanfaatan ${ }^{53}$, sedangkan dalam Pasal 6 ayat (5) UU PR yang diamanatkan adalah perihal pengaturan pengelolaan ruang laut. Perlu diketahui bahwa berbeda pengertian antara arahan pemanfaatan, arahan penetapan pemanfaatan,

46 Pasal 1 angka 2 dan 3 Undang-Undang Nomor 27 Tahun 2007 tentang Pengelolaan Wilayah Pesisir dan PulauPulau Kecil.

47 Pasal 1 angka 1 Undang-Undang Nomor 32 Tahun 2014 tentang Kelautan.

48 Mujio, Luky Adrianto, Kadarwan Soewardi, dan Yusli Wardiatno, "Analisis Potensi Konflik Pemanfaatan Ruang Kawasan Pesisir: Integrasi Rencana Tata Ruang Darat dan Perairan Pesisir", Sodality: Jurnal Sosiologi Pedesaan, Vol. 4, No. 2 (2016), hlm. 139.

49 Ibid.

50 Pasal 9 ayat (2) Undang-Undang Nomor 27 Tahun 2007 tentang Pengelolaan Wilayah Pesisir dan Pulau-Pulau Kecil.

51 Pasal 10 huruf c Undang-Undang Nomor 27 Tahun 2007 tentang Pengelolaan Wilayah Pesisir dan Pulau-Pulau Kecil.

52 Pasal 9 ayat (2) Undang-Undang Nomor 27 Tahun 2007 tentang Pengelolaan Wilayah Pesisir dan Pulau-Pulau Kecil.

53 Pasal 10 huruf c Undang-Undang Nomor 27 Tahun 2007 tentang Pengelolaan Wilayah Pesisir dan Pulau-Pulau Kecil. 
dan pengelolaan. Arahan pemanfaatan dan arahan penetapan pemanfaatan merujuk pada fungsi regelendaad ${ }^{54}$. Hal ini karena arahan pemanfaatan lazim masuk sebagai muatan dari Peraturan Pemerintah atau Peraturan Daerah, ${ }^{55}$ sedangkan pengelolaan merujuk pada beheersdaad, yakni fungsi pengelolaan dilakukan [...] mendayagunakan penguasaannya atas sumber-sumber kekayaan untuk digunakan bagi sebesar-besarnya kemakmuran rakyat. ${ }^{56}$

Keempat, Diferensiasi Alokasi Ruang. Merujuk pada UU PWP3K alokasi ruang yang diatur terdiri dari Kawasan Pemanfaatan Umum, Kawasan Konservasi, Kawasan Strategis Nasional Tertentu, dan alur laut, ${ }^{57}$ sedangkan dalam UU $\mathrm{PR}$, alokasi ruang terdiri dari Kawasan Lindung dan Kawasan Budidaya. ${ }^{58} \mathrm{Hal}$ ini menunjukkan bahwa struktur RZWP3K dengan struktur penataan ruang laut dalam UU PR sangat berbeda. Dengan demikian, RZWP3K sekaligus UU PWP3K bukan merupakan pengejawantahan Pasal 6 ayat (5) UU PR yang mengamanatkan adanya pengaturan sendiri perihal pengelolaan ruang laut. Berdasarkan hal tersebut, maka dapat disimpulkan bahwa RZWP3K dan perencanaan ruang laut mempunyai sangat banyak perbedaan yuridis, sehingga pengaturan ruang laut dalam RZWP3K tidak tepat atau setidaknya tidak cukup.

Di luar daripada itu, RZWP3K dan RTRW merupakan dokumen yang harusnya disusun secara integratif. Hal ini dengan jelas disebutkan dalam UU PWP3K bahwa, "RZWP-3-K diserasikan, diselaraskan, dan diseimbangkan dengan Rencana Tata Ruang Wilayah (RTRW) pemerintah provinsi atau pemerintah kabupaten/kota". ${ }^{59} \mathrm{Hal}$ ini sama halnya dengan rencana tata ruang laut, yang diuraikan sebagai berikut:

- Penataan ruang wilayah nasional meliputi ruang wilayah yurisdiksi dan wilayah kedaulatan nasional yang mencakup ruang darat, ruang laut, dan ruang udara, termasuk ruang di dalam bumi sebagai satu kesatuan. ${ }^{60}$

- Penataan ruang wilayah provinsi dan kabupaten/kota meliputi ruang darat, ruang laut, dan ruang udara, termasuk ruang di dalam bumi sesuai dengan ketentuan peraturan perundang-undangan. ${ }^{61}$

- Rencana Tata Ruang Wilayah Nasional, rencana tata ruang wilayah provinsi, dan rencana tata ruang wilayah kabupaten/ kota mencakup ruang darat, ruang laut,

54 Fungsi pengaturan oleh negara (regelendaad) dilakukan melalui kewenangan legislasi oleh DPR bersama Pemerintah, dan regulasi oleh Pemerintah. Lihat dalam Putusan Mahkamah Konstitusi Nomor 002/PUU-I/2003 tentang perihal Pengujian Undang-Undang Republik Indonesia Nomor 22 Tahun 2001 tentang Minyak dan Gas Bumi, 1 Januari 2005.

55 Misalnya dalam Pasal 20 ayat (1) huruf e dan ayat (6), Pasal 23 ayat (1) huruf e dan ayat (6) Undang-Undang Nomor 26 Tahun 2007 tentang Penataan Ruang. Lihat juga Pasal 20 ayat (2) huruf e dan Pasal 23 ayat (1) huruf d Undang-Undang Nomor 27 Tahun 2007 tentang Pengelolaan Wilayah Pesisir dan Pulau-Pulau Kecil.

56 Putusan Mahkamah Konstitusi Nomor 002/PUU-I/2003 tentang perihal Pengujian Undang-Undang Republik Indonesia Nomor 22 Tahun 2001 tentang Minyak dan Gas Bumi, 1 Januari 2005.

57 Pasal 10 huruf a Undang-Undang Nomor 27 Tahun 2007 tentang Pengelolaan Wilayah Pesisir dan Pulau-Pulau Kecil.

58 Pasal 5 ayat (2) Undang-Undang Nomor 26 Tahun 2007 tentang Penataan Ruang.

59 Pasal 9 ayat (2) Undang-Undang Nomor 27 Tahun 2007 tentang Pengelolaan Wilayah Pesisir dan Pulau-Pulau Kecil.

60 Pasal 6 ayat (3) Undang-Undang Nomor 26 Tahun 2007 tentang Penataan Ruang.

61 Pasal 6 ayat (4) Undang-Undang Nomor 26 Tahun 2007 tentang Penataan Ruang. 
dan ruang udara, termasuk ruang di dalam bumi. ${ }^{62}$

Berdasarkan uraian pengaturan tersebut, maka RZWP3K maupun rencana tata ruang laut harusnya integratif dengan RTRW, baik nasional, provinsi, maupun kabupaten/kota. Penyusunan tata ruang wilayah pesisir harus memperhatikan (diantaranya) hirarki rencana tata ruang wilayah. ${ }^{63}$

Kemudian, untuk mendukung integrasi antara RZWP3K, rencana tata ruang laut, dengan RTRW, maka menjadi penting untuk menganalisis instansi manakah yang berwenang menyusun RZWP3K sebagai bagian dari perencanaan ruang laut, dengan melihat pada Tabel Pembagian Urusan Bidang Kelautan dan Perikanan (Sub Urusan Kelautan, Pesisir, dan Pulau-Pulau Kecil dan Sub Urusan Pengawasan Sumber Daya Kelautan dan Perikanan). Wewenang Pemerintah Pusat dan Pemerintah Daerah Provinsi, Kabupaten/Kota yang berkaitan dengan "ruang laut", yakni: ${ }^{64}$

a. Wewenang Pemerintah Pusat: (a) pengelolaan ruang laut di atas 12 mil dan strategis nasional; (b) penerbitan izin pemanfaatan ruang laut nasional; dan (c) pengawasan sumber daya kelautan dan perikanan di atas 12 mil, strategis nasional dan ruang laut tertentu.

b. Wewenang Pemerintah Daerah Provinsi adalah pengelolaan ruang laut sampai dengan 12 mil di luar minyak dan gas bumi dan penerbitan izin dan pemanfaatan ruang laut di bawah 12 mil di luar minyak dan gas bumi.

Berdasarkan hal tersebut tidak ada satu pun kewenangan dalam Urusan Bidang Kelautan dan Perikanan yang berkaitan dengan penataan ruang laut, seperti yang dimaksud dalam Pasal 6 ayat (5) UU PR. Dengan demikian, seharusnya Dinas Kelautan dan Perikanan tidak mempunyai kewenangan untuk menyusun RZWP3K maupun rencana tata ruang laut.

Selanjutnya, dengan melihat pada Tabel Pembagian Urusan Pemerintahan Bidang Pekerjaan Umum dan Penataan Ruang (Sub Urusan Penataan Ruang), diatur bahwa: ${ }^{65}$

a. wewenang Pemerintah Pusat adalah: (a) penyelenggaraan penataan ruang wilayah nasional; dan (b) pelaksanaan kerja sama penataan ruang antarnegara.

b. wewenang Pemerintah Daerah Provinsi adalah penyelenggaraan penataan ruang wilayah Provinsi.

c. wewenang Pemerintah Daerah Kabupaten/ Kota adalah penyelenggaraan penataan ruang wilayah Kabupaten/Kota.

Berdasarkan uraian tersebut, maka jelas sudah bahwa yang berwenang menyusun RZWP3K maupun rencana tata ruang laut adalah Dinas yang membidangi urusan penataan ruang (dalam hal ini Dinas Pertanahan dan Tata Ruang) karena dengan merujuk pada pengertian "ruang" dalam Pasal 1 angka 1 UU PR. Hal ini

62 Pasal 15 Undang-Undang Nomor 26 Tahun 2007 tentang Penataan Ruang.

63 Rakhim Dahuri, Penataan Ruang Wilayah Pesisir, Pulau Kecil, dan Lautan untuk Meningkatkan Daya Saing dan Pertumbuhan Ekonomi Berkualitas secara Berkelanjutan Menuju Indonesia sebagai Poros Maritim Dunia, (Jakarta: Direktorat Jenderal Penataan Agraria, 2015), sebagaimana dikutip Waryanta, "Integrasi Penataan Pertanahan dalam Kerangka "Penataan Wilayah Pesisir dan Lahan atas Terpadu”, Bhumi, Vol. 2, No. 1, (Mei 2016), hlm. 21.

64 Lampiran Undang-Undang Nomor 23 Tahun 2014 tentang Pemerintah Daerah.

65 Lampiran Undang-Undang Nomor 23 Tahun 2014 tentang Pemerintah Daerah. 
penting untuk mendukung upaya penyerasian, penyelarasan, dan penyeimbangan RZWP3K dengan RTRW yang mencakup khususnya:66 Pertama, menyerasikan alokasi ruang perairan pesisir dan pulau-pulau kecil dalam RZWP3K yang bersinggungan dengan pola ruang dalam RTRW; Kedua, menyelaraskan pola ruang dan struktur ruang daratan pesisir RTRW ke dalam RZWP3K; dan Ketiga, menyeimbangkan rencana Pemerintah dan Pemerintah Daerah yang telah ditetapkan sesuai dengan peraturan perundangundangan dalam alokasi ruang perairan pesisir dalam RZWP3K.

\section{Penutup}

Berdasarkan analisis dan uraikan di atas, dapat disimpulkan bahwa konstruksi hukum dokumen RZWP3K dalam perencanaan spasial yakni: Pertama, tahapan penyusunan dokumen. Baik RZWP3K dan RTRW sama-sama: (a) melibatkan masyarakat dalam penyusunan/ perumusan konsepnya; dan (b) adanya upaya untuk mendapatkan masukan, tanggapan, dan saran perbaikan dalam pembahasan rancangan rencana tata ruang, namun khusus untuk RZWP3K usulan penyusunan dapat dilakukan oleh dunia bisnis. Kedua, kelembagaan penyusun dokumen. RZWP3K hanya dapat dibentuk pada level provinsi, sedangkan RTRW dapat dibentuk pada level nasional, provinsi, maupun kabupaten/kota. Ketiga, perbedaan sistematika dokumen. Keempat, penuangan dokumen dalam produk hukum. Merujuk pada uraian sebelumnya, RZWP3K dituangkan dalam produk hukum berupa Peraturan Daerah Provinsi, sedangkan RTRW dituangkan dalam produk hukum berupa Peraturan Daerah Provinsi atau Kabupaten/Kota.

Kompatibilitas RZWP3K sebagai rencana tata ruang laut yang integratif dengan dokumen perencanaan spasial lainnya. Perbedaan yuridis antara RZWP3K dengan rencana tata ruang laut: (a) diferensiasi definisi antara pengertian "wilayah pesisir" dan "laut" dalam UU PWP3K dan UU Kelautan; (b) diferensiasi substansi, pertentangan antara Pasal 9 ayat (2) dengan Pasal 10 c UU PWP3k sebab dengan merujuk pada Pasal 1 angka 2 dan 3 UU PWP3K dan Pasal 1 angka 1 UU Kelautan perihal arahan pemanfaatan sumber daya di Wilayah Pesisir dan Pulau-Pulau Kecil, maka RZWP3K tidak dapat mencakup penetapan ruang laut, karena sumber daya di Wilayah Pesisir dan Pulau-Pulau kecil tidak mencakup ruang laut; (c) diferensiasi kewenangan, perihal arahan pemanfaatan dan arahan penetapan pemanfaatan, sedangkan dalam Pasal 6 ayat (5) UU PR yang diamanatkan adalah perihal pengaturan pengelolaan ruang laut; (d) Keempat, diferensiasi alokasi ruang, dalam UU PWP3K alokasi ruang yang diatur terdiri dari Kawasan Pemanfaatan Umum, Kawasan Konservasi, Kawasan Strategis Nasional Tertentu, dan alur laut, sedangkan dalam UU PR, alokasi ruang terdiri dari Kawasan Lindung dan Kawasan Budidaya. Berdasarkan hal tersebut maka RZWP3K dan rencana tata ruang laut adalah dua hal yang berbeda. Namun dengan merujuk pada pengaturan hukum positif RZWP3K (yang merupakan bagian dari rencana tata ruang laut) harus disusun secara integratif dengan RTRW dengan merujuk pada Pasal 6 ayat (3), (4), dan Pasal 15 UU PR. Dalam rangka

66 Direktur Tata Ruang dan Pertanahan Kementerian Perencanaan Pembangunan Nasional/Badan Perencanaan Pembangunan Nasional, "Penyerasian, Penyelarasan, dan Penyeimbangan RZWP3K dengan RTRW", (Paparan, Surabaya, November 2014). 
mewujudkan hal tersebut penyusunan RZWP3K maupun RTRW harus ada pada 1 (satu) instansi yakni Dinas yang membidangi urusan penataan ruang (merujuk pada Lampiran UU Pemda).

\section{DAFTAR PUSTAKA}

\section{Buku}

Satria, Arif, Politik Kelautan dan Perikanan (Jakarta: Yayasan Pustaka Obor Indonesia, 2015).

Soekanto, Soedjono, dan Sri Mamudji, Penelitian Hukum Normatif: Suatu Tinjauan Singkat, (Jakarta: Raja Grafindo Persada, 1994).

Soekanto, Soerdjono, Pengantar Penelitian Hukum, (Jakarta: UI Press, 1986).

\section{Makalah/ Artikel/ Laporan/ Hasil Penelitian}

Direktur Tata Ruang dan Pertanahan Kementerian Perencanaan Pembangunan Nasional/ Badan Perencanaan Pembangunan Nasional, "Penyerasian, Penyelarasan, dan Penyeimbangan RZWP3K dengan RTRW", (Paparan, Surabaya, November 2014).

Mujio, Luky Adrianto, Kadarwan Soewardi, dan Yusli Wardiatno, "Analisis Potensi Konflik Pemanfaatan Ruang Kawasan Pesisir: Integrasi Rencana Tata Ruang Darat dan Perairan Pesisir", Sodality: Jurnal Sosiologi Pedesaan, Vol. 4, No. 2 (2016).

Soedradjat, Iman, "Penyelarasan Rencana Zonasi Wilayah Pesisir dan Pulau-Pulau Kecil (RZWP3K) dan Rencana Tata Ruang Wilayah (RTRW)", Buletin Tata Ruang \& Pertanahan, Edisi I (2013).

Syahbuddin, Haris, "Penataan Ruang Wilayah: Perjalanan Panjang Bangsa", Inovasi, Vol. 7, No. XVIII (Juni 2006).

Waryanta, "Integrasi Penataan Pertanahan dalam Kerangka "Penataan Wilayah Pesisir dan Lahan atas Terpadu", Bhumi, Vol. 2, No. 1, (Mei 2016).

\section{Internet}

DJPP Kemenkumham, "RPP tentang Rencana Tata Ruang Laut Nasional", http://ditjenpp. kemenkumham.go.id/kegiatan-umum/3150rpp-tentang-rencana-tata-ruang-laut-nasional. html (diakses 15 Juni 2017).

Kasworo, Yerrico, "Urgensi Penyusunan Pengaturan Rencana Zonasi Wilayah Pesisir dan Pulau-Pulau Kecil", Rechtsvinding Online, (2017), http:// rechtsvinding.bphn.go.id/view/view_online. php?id=233 (diakses 15 Juni 2017).

\section{Putusan Pengadilan}

Putusan Mahkamah Konstitusi Nomor 002/ PUU-I/2003 tentang perihal Pengujian UndangUndang Republik Ind

onesia Nomor 22 Tahun 2001 tentang Minyak dan Gas Bumi, 1 Januari 2005.

\section{Peraturan}

Undang-Undang Dasar Negara Republik Indonesia Tahun 1945.

Undang-Undang Nomor 26 Tahun 2007 tentang Penataan Ruang

Undang-Undang Nomor 27 Tahun 2007 tentang Pengelolaan Wilayah Pesisir dan Pulau-Pulau Kecil

Undang-Undang Nomor 32 Tahun 2009 tentang Perlindungan dan Pengelolaan Lingkungan Hidup

Undang-Undang Nomor 12 Tahun 2011 tentang Pembentukan Peraturan Perundang-undangan

Undang-Undang Nomor 23 Tahun 2014 tentang Pemerintah Daerah

Undang-Undang Nomor 32 Tahun 2014 tentang Kelautan

Peraturan Pemerintah Nomor 15 Tahun 2010 tentang Penyelenggaraan Penataan Ruang 